\title{
Jan Cebulak
}

Podkarpacka Szkoła Wyższa

im. bł. ks. Władysława Findysza w Jaśle

\section{Czynniki warunkujące tworzenie sieci wspólpracy w regionie Podkarpacia}

Sieci współpracy (klastry - grona, grupy, skupienia) przedsiębiorstw są nieodłącznym elementem krajobrazu każdej współczesnej gospodarki. Poprzez kreowanie polityki regionalnej, polityki innowacyjnej oraz tworzenie klastrów wdrażany jest proces podnoszenia innowacyjności regionu i poszczególnych przedsiębiorstw. Lokalny system informacji to klaster, który powinien dostarczać informacji na temat osiagnięć naukowych, możliwości wprowadzania innowacji, a także pomagać w zdobywaniu kapitału, promocji, marketingu. Główną funkcją samorządów regionalnych i lokalnych jest kreowanie rozwoju społeczno-gospodarczego swoich obszarów w celu podniesienia poziomu życia jego mieszkańców. Realizując tę funkcję, samorządy nie mogą być bierne, czyli czekać na wyniki samoczynnie działających mechanizmów rynkowych, lecz muszą wykazywać się aktywnością i podejmować różnego typu działania mieszczące się w ich polityce przemysłowo-innowacyjnej służącej podnoszeniu konkurencyjności wybranych sektorów gospodarczych działających w regionach. Działania te powinny stanowić ważny element $\mathrm{w}$ systemie programowania rozwoju regionalnego i lokalnego, tj. zarówno w programowaniu społeczno-gospodarczym, jak i programowaniu finansowym, a zatem winny stanowić ważną część regionalnych i lokalnych strategii rozwoju.

W nowych uwarunkowaniach ekonomicznych i organizacyjno-instytucjonalnych największe możliwości osiągania korzyści przez przedsiębiorstwa oraz kreowania innowacji w gospodarce stwarzają formy organizacyjne oparte na powiązaniach sieciowych. Według definicji OECD, sieć to „specyficzna forma powiązań pomiędzy podmiotami oparta na wzajemnych współzależnościach, kooperacji i zaufaniu (Gurbała 2004, s. 26). Pojawienie się zinstytucjonalizowanych lub nieformalnych sieci, tworzonych przez skupiska firm i grup poziomo powiązanych filii przedsiębiorstw, to główna nowa cecha współczesnej gospodarki. Nowe formy organizacyjne pozwalają na większą koordynację pomiędzy qasi- niezależnymi aktorami i równocześnie zwiększają elastyczność planowania, produkcji i dystrybucji. Sieci mogą mieć charakter zarówno przestrzenny, jak i aprzestrzenny, występujący np. w przypadku przepływów elektronicznych (Brodzicki, Szultka, 2002 s. 15).

Grona opierają się na współpracy i konkurencyjności stymulującej innowacyjność będącą główną ścieżką wzrostu konkurencyjności i rentowności przedsiębiorstw. Od siły przedsiębiorstw zależy kondycja całej gospodarki. Dotychczasowe doświadczenia zagraniczne w zakresie wspierania rozwoju struktur klastrowych wskazują, że nie ma standardowej polityki klastrowej, uniwersalnego modelu, który można implementować bez względu na uwarunkowania zewnętrzne. Regiony różnią się otoczeniem prawnym i administracyjnym, zakresem rozwoju infrastruktury, jakością instytucji okołobiznesowych, a także stopniem rozwoju systemu finansowego. Różnice dotyczą także zakresu rozwoju i wykorzystywania w regionie 
technologii informatycznych i komunikacyjnych, struktury gospodarczej, społecznej i demograficznej, potencjału innowacyjnego (w tym poziomu zakumulowanej wiedzy). Inne są źródła pozyskiwania technologii, kwalifikacje zasobów ludzkich czy też model współpracy kooperacyjnej firm. Struktury klastrowe są obecnie najlepiej zdiagnozowanym, jednym z najskuteczniejszych narzędzi z zakresu polityki gospodarczej, których celem jest stymulowanie współpracy horyzontalnej, a w efekcie konkurencyjności i innowacyjności regionów oraz małych i średnich firm.

Skuteczne narzędzia z obszarów polityki gospodarczej (na poziomie centralnym i regionalnym), których celem jest wspieranie powstawania i rozwoju gron, są szczególnie istotne w przypadku regionów o niższym poziomie rozwoju i konkurencyjności. Za pomocą tych narzędzi można niwelować zagrożenia oraz wykorzystywać szanse, jakie niesie ze sobą postępujący proces globalizacji, jak również tworzyć skuteczne mechanizmy wsparcia funkcjonowania firm i poprawy otoczenia prowadzenia działalności gospodarczej. Struktury klastrowe to efektywny mechanizm stymulowania konkurencyjności sektora małych i średnich przedsiębiorstw (MŚP). Głównym problemem rozwoju małych i średnich przedsiębiorstw jest skala działalności w kontaktach z dostawcami, instytucjami finansowymi i doradczymi. Struktury klastrowe pomagają niwelować bariery rozwoju sektora MŚP, co jest szczególnie istotne, gdyż sektor MŚP tworzy nowe miejsca pracy na obszarach słabo zurbanizowanych, a województwo podkarpackie charakteryzuje się najniższym wskaźnikiem stopnia urbanizacji w Polsce (42\% w 2008 r.). Dodatkowo jest to jeden z najsłabiej rozwiniętych gospodarczo regionów w Polsce (w 2008 r. PKB na 1 mieszkańca w województwie podkarpackim stanowił ok. 27\% średniej UE).

Proces tworzenia sieci współpracy jest istotny nie tylko dla przedsiębiorców, lecz przede wszystkim dla władz i działaczy samorządowych odpowiedzialnych za stymulowanie procesów rozwoju lokalnego i regionalnego. W okresie członkostwa we Wspólnocie Europejskiej pojawiły się oparte na funduszach strukturalnych programy wsparcia rozwoju nie tylko klastrów, ale i szerzej powiązań kooperacyjnych. W okresie 2004-2006, a także w bieżącym okresie finansowania 2007-2013, Samorząd Województwa Podkarpackiego był instytucją wdrażającą dla działania 2.6 Regionalne Strategie Innowacyjne i Transfer Wiedzy w ramach ZPORR oraz aktualnie wdraża Regionalny Program Operacyjny woj. podkarpackiego wspierający przedsięwzięcia mające na celu tworzenie klastrów przedsiębiorczości na Podkarpaciu. W założeniach tych dokumentów określono klastry jako lokalne systemy informacji prowadzące do powstania silnego, regionalnego systemu innowacji podnoszącego konkurencyjność i poziom gospodarki regionalnej. Działalność Samorządu Województwa Podkarpackiego w zakresie regionalnej polityki innowacyjnej wspierającej m.in. tworzenie gron przedsiębiorstw określona została w Regionalnej Strategii Innowacji na lata 2005-2013. Kierunki działań innowacyjnych oraz zakres i formy wsparcia instrumentami finansowymi głównie z Europejskiego Funduszu Społecznego i z budżetu państwa ustala Podkarpacka Rada Innowacyjności. Organizacja ta powstała w 2005 r. i utworzona została z przedstawicieli sektora gospodarki, nauki, ekspertów w zakresie innowacji oraz reprezentantów samorządu wojewódzkiego i samorządów lokalnych.

W świetle zasygnalizowanego problemu rozwoju regionu podkarpackiego i kształtowania jego konkurencyjności podjęto próbę identyfikacji endogenicznych czynników mających wpływ na ten proces. Dotyczyło to głównie tworzenia sieci współpracy i innych form współdziałania, których uruchomienie i organizacja w regionie Podkarpacia wymaga aktywnych działań ze strony instytucji odpowiedzialnych za rozwój regionalny. Analizę przeprowadzono na podstawie danych statystycznych charakteryzujących badaną problematykę, a dotyczących 
lat 2004-2008, publikowanych przez GUS. Ocena materiału empirycznego daje wykładnię co do stanu zaawansowania procesu tworzenia sieci współpracy w regionie Podkarpacia.

\section{Istota sieci współpracy oraz koncepcje pokrewne i komplementarne}

Współpraca z innymi przedsiębiorstwami, a także placówkami badawczo-rozwojowymi oraz tworzenie sieci umożliwia osiągnięcie przewagi w stosunku do sztywnych zhierarchizowanych struktur. W praktycznym działaniu jest to możliwe pod warunkiem:

- korzystania z większej liczby kanałów umożliwiających uczenie się i tworzenie wiedzy fachowej - uczenie się od innych przedsiębiorstw (konkurentów, dostawców, odbiorców) jest efektywnym sposobem pozyskiwania dla organizacji dużego zasobu wiedzy potrzebnej do innowacji,

- osiagania korzyści skali - sieci skierowane na łączenie sprzedaży i dystrybucji lub dzielenie się posiadanym zapleczem (w tym wiedzą) mogą obniżać koszty ponoszone przez poszczególne przedsiębiorstwa w sytuacji, gdy koszty ponoszone na $\mathrm{B}+\mathrm{R}$ mogą być dzielone i wówczas rozprzestrzenianie się wiedzy nabiera tempa,

- osiagania korzyści różnorodności - połączona wiedza może otworzyć nowe nisze rynkowe, sieci są zatem lepiej przystosowane do radzenia sobie ze wzrastającym popytem na towary wysokiej jakości,

- zwiększania elastyczności i dzielenia się ryzykiem - tworzenie zasobu wiedzy w elastycznej sieci zwiększa możliwości sprostania przez przedsiębiorstwo wyzwaniom rynkowym.

W sytuacji szybko zmieniających się warunków technologicznych i organizacyjnych odchodzi się od ujmowania innowacji w kontekście jednego przedsiębiorstwa traktowanego jako izolowany podmiot. Praktyka dowodzi, że innowacje coraz częściej powstają w ramach sieci firm współpracujących ze sobą na wiele sposobów. W układach sieciowych strategiczną rolę odgrywa przeważnie jedna firma (final assembler), lecz produkt końcowy zawiera ucieleśniony (rzeczowy) i nieucieleśniony wkład innych firm, a także innych instytucji. Sieciowość jest jedną z charakterystyk współczesnej strategii korporacji obok strategii technologicznej, zintegrowanej strategii dotyczącej produktu, elastyczności (również organizacyjnej), znaczenia środowiska, szybkości wprowadzania innowacji i zdobywania rynku (Rothwell 1992).

Dla wszystkich form sieci przemysłowych charakterystyczne są takie cechy, jak:

- współzależność aktorów i partnerstwo polegające na przekonaniu, iż wzajemne relacje są podstawą sukcesu,

- wzajemność świadczeń będąca warunkiem koniecznym efektywnej wymiany informacji i wiedzy, odróżniająca sieć systemów hierarchicznych,

- zaufanie rozumiane jako przekonanie o solidności innych podmiotów,

- luźne powiązania, które zapewniają duży stopień otwartości i autonomii w wyborze partnerów, możliwość szybkiej reakcji na zmiany warunków zewnętrznych oraz ułatwiające adaptację innowacji,

- władza i pełnomocnictwo - mimo współzależności uczestników sieci i wzajemności świadczeń rozkład władzy w ramach sieci nie jest symetryczny.

Ważnymi elementami sieci są jednostki terytorialne i instytucje funkcjonujące na danym obszarze (władze regionalne, agencje rozwoju itp.). Ponadto atrybutem każdej sieci jest „osadzenie" społeczne i instytucjonalne, czyli wyposażenie danego obszaru w elementy sprzyjające kształtowaniu się określonych relacji. Analiza sieci przedsiębiorstw wymaga zatem uwzględnienia ich otoczenia lokalnego i regionalnego, gdyż dopiero kooperacja firm przy efektywnym zaangażowaniu instytucji zewnętrznych o różnym charakterze, tworząc korzystne warunki do powstania wiedzy i stymulując proces uczenia się, prowadzi do pełnego 
wykorzystania możliwości rozwojowych (Olechnicka 2004). Zachodzi ścisły związek pomiędzy sieciowym zaangażowaniem przedsiębiorstwa i uwarunkowaniami tworzenia wiedzy. W tym kontekście wyróżnia się trojakiego rodzaju powiązania sieciowe: stałe, zmienne i ewolucyjne. Najmniej sprzyjającą tworzeniu wiedzy formą sieci jest sieć typu stałego, w którym wewnętrzny podział pracy między przedsiębiorstwami jest trwały, a specjalizacja przedsiębiorstw relatywnie niska. Drugi typ sieci, czyli sieć zmienna, charakteryzuje się tym, iż firmy w ramach tej sieci rozwijają możliwości imitującego, przystosowawczego uczenia skoncentrowanego na wprowadzaniu drobnych innowacji, chociażby w niektórych węzłach sieci. Najbardziej efektywną formą organizacyjną jest sieć ewolucyjna charakteryzująca się wysoką elastycznością, różnymi formami kreacji wiedzy oraz wzrastającymi możliwościami technologicznymi.

Współczesne przemiany społeczno-ekonomiczne zmierzające w kierunku kształtowania się społeczeństwa i gospodarki informacyjnej powodują konieczność poszukiwania nowych sposobów zastosowania istniejącej wiedzy w systemie ekonomicznym oraz tworzenia nowej wiedzy. W rozwoju opartym na wiedzy optymalną formą organizacji życia społeczno-gospodarczego są powiązania sieciowe, które dzięki właściwej im elastyczności pozwalają na nieprzerwane dostosowywanie się do zmieniających się warunków zewnętrznych, sprzyjają innowacyjności, ułatwiają i przyśpieszają tworzenie oraz rozprzestrzenianie się wiedzy.

Słowo „klaster”" po raz pierwszy zostało użyte przez Portera (1990) i wg jego definicji to ,geograficzne skupisko wzajemnie powiązanych firm, wyspecjalizowanych dostawców, jednostek świadczących usługi, firm działających w pokrewnych sektorach i związanych z nimi instytucji (uniwersytetów, jednostek normalizacyjnych i stowarzyszeń branżowych) w poszczególnych dziedzinach, konkurujących między sobą, ale również współpracujących. Klastry osiągające masę krytyczną (niezbędna liczba firm i innych instytucji tworząca efekt aglomeracji) i odnoszące niezwykłe sukcesy konkurencyjne w określonych dziedzinach działalności są uderzającą cechą niemal każdej gospodarki narodowej, regionalnej, stanowej, a nawet wielkomiejskiej, głównie w krajach gospodarczo rozwiniętych (Porter 2001, s. 98). Obok klasycznej definicji Portera w literaturze przedmiotu funkcjonuje wiele innych definicji klastra $^{2}$. Większość z nich za główne wyznaczniki klastra uznaje trzy podstawowe czynniki: koncentrację na określonym obszarze współzależnych przedsiębiorstw działających w tych samych lub pokrewnych sektorach przemysłu lub usług, interakcje i funkcjonalne powiązania pomiędzy firmami, ponadsektorowy wymiar klastra obejmującego swym zasięgiem zarówno horyzontalne, jak i wertykalne powiązania. Niektórzy autorzy ${ }^{3}$ zwracają uwagę na duże znaczenie czynników społecznych i kulturowych dla sprawnego przepływu informacji w klastrze. Definicje te jednak w sposób bardzo zróżnicowany akcentują niektóre inne elementy determinujące budowę klastra: charakter innowacji, kierunek i siłę powiązania w ramach łańcuchów produkcyjnych, przepływ wiedzy i technologii, bliskość geograficzna, specjalistyczną infrastrukturę, wykwalifikowaną siłę roboczą czy usługi wspierające. Uwzględniając te czynniki, klaster może być rozumiany jako przestrzennie skoncentrowane skupisko przedsiębiorstw

\footnotetext{
${ }^{1}$ Słowo cluster oznacza 'grupę podobnych rzeczy wzrastających bądź utrzymujących się razem, grupę ludzi lub rzeczy znajdujących się blisko siebie'.

2 Jacobs J. (2000), The Nature of Ekonomics, New York; 58, Rosenfeld S.A. (2002), Creating Smart Systems. A. Guide to Cluster Strategies in Less Favoured Regions, Regional Technology Strategies, s. 45.

${ }^{3}$ Ketels Ch. (2003), The Development of the cluster concept, Harvard Business School, s. 153.

Moss R. (1995), Kantor World Class, Simon\&Schuster, New York, s. 153.

Enright M. (1998), The Globalization of Competition and the Localization, Simon\&Schuster, s. 120.
} 
jednocześnie konkurujących i kooperujących ze sobą w pewnych aspektach działalności oraz instytucji i organizacji, powiązanych rozbudowanym systemem wzajemnych relacji o formalnym i nieformalnym charakterze, opartych na specyficznej trajektorii rozwoju (np. technologia, rynki zbytu itp.). Wszystkie koncepcje rozwoju klastra oparte zostały o przewagę lokalizacyjną i podejście systemowe, stanowiły rozwinięcie i uzupełnienie bazowej teorii określonej przez Portera (tabela 1).

Koncepcje te, poszukując nowych źródeł przewagi konkurencyjnej, rozszerzyły zakres podmiotowy skupisk, włączając również różnego typu instytucje i organizacje lokalnego otoczenia przedsiębiorstw. Klastry w ujęciu przedmiotowym stanowią specyficzną formę przestrzennej organizacji sektorów przemysłu i usług uważaną za najbardziej dojrzałą formę organizacji produkcji z punktu widzenia zdolności do podtrzymywania rozwoju (Górzyński, 2006 s. 67). Ich cechą charakterystyczną jest zdolność do generowania i utrzymania przewagi konkurencyjnej. W literaturze przedmiotu wymieniane są korzyści, które dla lokalnej, regionalnej, czy też narodowej gospodarki przynosi funkcjonowanie systemu produkcji typu klastrowego. Efektywnie funkcjonujący klaster prowadzi do wzrostu produktywności lokalnych przedsiębiorstw ze względu na dostęp do relatywnie tanich, wyspecjalizowanych czynników produkcji oraz różnorodnych nakładów wykorzystywanych w działalności produkcyjnej. Ponadto przestrzenna bliskość podmiotów gospodarczych stymuluje i wspiera ich innowacyjność. Rozwijający się klaster charakteryzuje dynamiczny wzrost liczby nowo powstałych przedsiębiorstw, co przekłada się na kreowanie nowych miejsc pracy. Efektywnie funkcjonujący klaster powoduje również wzrost dostępności specjalistycznych usług okołobiznesowych, inwestycje w infrastrukturę, zwiększenie dochodów ludności. Klaster staje się swoistym motorem rozwoju regionalnego. W procesie tworzenia sieci współpracy istotne znaczenie mają instytucje społeczne, tj. władze państwowe, związki zawodowe, organizacje finansowe, organizacje społeczno-polityczne, a także struktury własnościowe, organizacyjne i inne (Wilkin 2001, s. 120).

Znaczenie pojęciowe instytucji jest bardzo szerokie i różnorodnie interpretowane przez przedstawicieli poszczególnych dyscyplin naukowych. Według D.C. Northa, przedstawiciela nowej ekonomii instytucjonalnej, są to trwałe, prawne, organizacyjne i zwyczajowe uwarunkowania powtarzalnych ludzkich zachowań i międzyludzkich interakcji (North 1990, s. 58). $\mathrm{Z}$ tego wynika, że instytucja to zespół funkcjonalnie powiązanych norm prawnych i zasad, jak również wyodrębniona struktura organizacyjna (organizacje) i mechanizmy jej funkcjonowania.

W literaturze przedmiotu stosuje się wiele definicji klastrów (gron). Do najpopularniejszych zaliczyć należy definicje OECD, UNIDO oraz omawiana powyżej definicja M. Portera (Knop, Krannich, Machnik-Słomka, Wróbel 2005, s. 21).

Według definicji OECD klastry to geograficzne koncentracje wzajemnie powiązanych ze sobą przedsiębiorstw i instytucji danego obszaru działalności gospodarczej.

M. Porter definiuje klastry jako geograficzne koncentracje wzajemnie powiązanych przedsiębiorstw, wyspecjalizowanych dostawców ( $w$ tym dostawców usług), przedsiębiorstw z innych powiązanych sektorów i branż oraz instytucji otoczenia gospodarczego (np. uniwersytetów, izb handlowych) wzajemnie konkurujących oraz współpracujących.

Według UNIDO klastry to regionalne i terytorialne koncentracje firm produkujących i sprzedających podobne lub komplementarne produkty, a przez to zmuszonych do przezwyciężania podobnych problemów i wyzwań. W rezultacie może to powodować powstawanie wyspecjalizowanych dostawców maszyn i surowców oraz powodować rozwój specjalistycznych kompetencji i umiejętności, jak również szybszy rozwój specjalistycznych i zindywidualizowanych usług. 
Tab. 1. Koncepcje skupień gospodarczych

\begin{tabular}{|c|c|}
\hline Koncepcja & Główne cechy charakterystyczne \\
\hline $\begin{array}{l}\text { Okręg } \\
\text { przemysłowy }\end{array}$ & $\begin{array}{l}\text { Skoncentrowane przestrzennie skupisko wzajemnie powiązanych przedsiębiorstw } \\
\text { jednego bądź pokrewnych sektorów, w ramach którego pojawia się pozytywny efekt } \\
\text { aglomeracji oparty na trzech zasadniczych źródłach: przepływie wiedzy pomiędzy } \\
\text { przedsiębiorstwami, kreowaniu przez wspierające sektory przemysłu wyspecjalizo- } \\
\text { wanych czynników produkcji i usług oraz wyłonieniu się dostosowanego do potrzeb } \\
\text { dystryktu wyspecjalizowanego rynku wykwalifikowanej siły roboczej (Marshall 1920). }\end{array}$ \\
\hline $\begin{array}{l}\text { Biegun } \\
\text { wzrostu }\end{array}$ & $\begin{array}{l}\text { Biegunami tymi mogą być z jednej strony niektóre branże czy przedsiębiorstwa wy- } \\
\text { różniające się wysoką dynamiką rozwoju, a ponadto mające dużą skalę produkcji oraz } \\
\text { liczne powiązania z innymi gałęziami produkcji. } Z \text { drugiej strony biegunami wzrostu } \\
\text { mogą być niektóre społeczności lokalne, wyróżniające się przedsiębiorczością } \\
\text { i innowacyjnością, pobudzające rozwój w skali regionalnej (Perroux 1956). }\end{array}$ \\
\hline $\begin{array}{l}\text { Strefy wzrostu } \\
\text { (development blocks) }\end{array}$ & $\begin{array}{l}\text { Współzależności pomiędzy przedsiębiorstwami i sektorami ułatwiające } \\
\text { przepływ wiedzy (Dahmen 1988). }\end{array}$ \\
\hline $\begin{array}{l}\text { Bloki kompetencji } \\
\text { (competence } \\
\text { block Eliasson) }\end{array}$ & $\begin{array}{l}\text { Współwystępowanie pewnej liczby różnych kompetencji (klientów, którzy tworzą } \\
\text { popyt, innowatorów tworzących nowe produkty, przedsiębiorców identyfikujących } \\
\text { potencjalne innowacje, fundusze venture capital), które razem przyczyniają się } \\
\text { do rozwoju i komercjalizacji określonych produktów (Fridh 2000). }\end{array}$ \\
\hline $\begin{array}{l}\text { Kompleksy } \\
\text { przemysłowe }\end{array}$ & $\begin{array}{l}\text { Koncentrują się na powiązaniach między firmami rozwijającymi nowe technologie } \\
\text { (w postaci komponentów, maszyn i systemów produkcyjnych) z jednej strony, } \\
\text { a firmami wykorzystującymi te technologie } \\
\text { z drugiej (Drejer et.all 1997). }\end{array}$ \\
\hline $\begin{array}{l}\text { Obszary } \\
\text { zasobowe } \\
\text { (resource areas) }\end{array}$ & $\begin{array}{l}\text { Obszar taki obejmuje szeroki wachlarz produktów i usług, który jest relatywnie stabilny } \\
\text { w czasie i ma znaczący udział w gospodarce. Składa się z współzależnych sektorów } \\
\text { w związku z koniecznością kooperacji przy produkcji końcowego produktu bądź usługi. } \\
\text { W jego skład może również wchodzić sektor publiczny. Firmy z danego obszaru mają } \\
\text { takie same potrzeby pod względem warunków produkcyjnych. }\end{array}$ \\
\hline $\begin{array}{l}\text { Lańcuchy } \\
\text { produkcyjne }\end{array}$ & $\begin{array}{l}\text { Oparte na pionowych powiązaniach w procesach produkcyjnych; ich jądra stanowią } \\
\text { przedsiębiorstwa sąsiadujące w łańcuchu wartości dodanej. Czasami obejmuje również } \\
\text { jednostki naukowe, usługi okołobiznesowe oraz instytucje pośredniczące. }\end{array}$ \\
\hline $\begin{array}{l}\text { Środowisko } \\
\text { innowacyjne } \\
\text { (innovative millieux) }\end{array}$ & $\begin{array}{l}\text { Obszar koncentracji przemysłu wysokich technologii charakteryzujący się synergią } \\
\text { czynników ekonomicznych i instytucjonalnych prowadzącą do efektywnej kreacji } \\
\text { i dyfuzji wiedzy oraz wydajnego procesu } \\
\text { uczenia się. }\end{array}$ \\
\hline $\begin{array}{l}\text { Systemy } \\
\text { technologiczne }\end{array}$ & $\begin{array}{l}\text { Sieć lub sieci podmiotów współpracujących w danym obszarze technologii w celu gene- } \\
\text { rowania, dyfuzji oraz wykorzystywania tych technologii. Koncentruje się na przepływie } \\
\text { wiedzy i kompetencji, a nie na przepływie dóbr i usług. }\end{array}$ \\
\hline Sieci & $\begin{array}{l}\text { Specyficzna forma powiązań pomiędzy podmiotami oparta na wzajemnych współza- } \\
\text { leżnościach, kooperacji i zaufaniu (może, lecz nie musi być skoncentrowana } \\
\text { przestrzennie). }\end{array}$ \\
\hline
\end{tabular}

Źródło: opracowano na podstawie Brodzicki T., Szultka S., 2002. 
Według M. Portera (Porter 2001) do najważniejszych korzyści funkcjonowania klastrów należy zaliczyć:

- wyższą efektywność funkcjonowania firm wynikającą z możliwości dostępu do wyspecjalizowanych aktywów i dostawców, którzy mogą w ramach struktur klastrowych reagować szybciej niż firmy działające oddzielnie,

- firmy i instytucje w strukturach klastrowych mogą osiagnąć wyższy poziom innowacyjności dzięki występowaniu tzw. knowledge spillover, czyli dyfuzji wiedzy,

- podnosi się poziom tzw. business formation, a w efekcie ogólny poziom przedsiębiorczości w regionie.

Cechą charakteryzującą struktury klastrowe, niezwykle istotną z punktu widzenia projektowania instrumentów wsparcia i rozwoju jest ,cykl życia grona”, tj.:

- faza powstania (tzw. embrionalna) - siłą sprawczą powstawania grona są innowacje, innowatorzy, wewnętrzne instytucje; na tym etapie innowatorzy tworzą nowe idee, rynki, procesy, działania interwencyjne w tej fazie cyklu życia grona obejmują następujące aspekty: inwestowanie w masę krytyczną klastra oraz pobudzanie świadomości;

- faza rozwoju grona - ma miejsce, gdy rynek na produkty (wyroby lub usługi klastra) jest dostatecznie rozwinięty; w tej fazie rozwoju pojawia się coraz więcej firm (głównie konkurenci) oraz tworzą się firmy „odpryskowe”, następuje rozwój wzajemnych relacji, obserwowany jest wzrost presji konkurencyjnej, o sile napędowej klastra i rozwoju „ekonomii skali" decydują procesy imitacyjne i konkurencja, co sprzyja dalszemu rozwojowi innowacji;

- faza dojrzałości grona - procesy i produkty zaczynają być standardowe, a cena staje się być głównym czynnikiem konkurencji, w ramach klastra widoczna jest coraz większa presja konkurencji;

- faza schyłkowa - produkty i usługi są zastępowane przez inne, tańsze produkty lub substytuty.

Literatura przedmiotu wymienia kluczowe czynniki decydujące o powodzeniu powstawania i rozwoju gron. Najważniejsze wyniki badań z tego zakresu przedstawiają się następująco:

Moss definiuje zdolność grona do rozwoju jako zdolność i możliwości tworzenia nowych innowacyjnych i konkurencyjnych struktur gospodarczych, Moss wymienia następujące kluczowe czynniki sukcesu rozwoju grona (Moss 1995, s. 65):

- elastyczność i otwartość struktury klastrowej, która umożliwia dostęp do nowej technologii, wiedzy i informacji,

- wysoką jakość powiązań i wzajemne zaufanie w relacjach pomiędzy uczestnikami grona - kluczowy czynnik sukcesu w zakresie skutecznego funkcjonowania mechanizmu dyfuzji innowacji i wiedzy,

- poziom kompetencji i jakość zasobów ludzkich - w ocenie R. Moss jest to decydujący czynnik skutecznego transferu i dyfuzji wiedzy.

Szczególnie istotnym czynnikiem sukcesu rozwoju struktur klastrowych wymienianym w literaturze przedmiotu jest jakość i poziom kompetencji zasobów ludzkich. Jacobs w swojej pracy dowodzi, że wykwalifikowane zasoby ludzkie to kluczowy czynnik sukcesu w dobie globalizacji i rozwoju internetu, zwraca również uwagę, że w procesie kształtowania i rozwoju struktur klastrowych szczególną rolę odgrywają tzw. liderzy przemysłowi (Jacobs 2000, s. 58).

Porter za kluczowy czynnik rozwoju klastrów uważa otoczenie biznesowe, które charakteryzuje za pomocą czterech obszarów (Porter 1995, s. 86):

- dostępnych zasobów (infrastruktura, umiejętności itp.),

- popytu wewnętrznego (wymagania lokalnych odbiorców), 
- ogólnego poziomu przedsiębiorczości oraz jakości regulacji prawnych stymulujących przedsiębiorczość (opodatkowanie, lokalne strategie konkurencyjności firm, prawo konkurencji itp.),

- innych wspomagających przemysłów - dostawców i odbiorców (tzw. zasięg i głębokość klastra).

Ketels, podobnie jak Porter, również wskazuje na otoczenie instytucjonalne i prawne jako na główny czynnik decydujący o powodzeniu rozwoju struktur klastrowych (Ketels 2003, s. 153). Ketels analizował funkcjonowanie klastrów w krajach słabo rozwiniętych oraz na obszarach gorzej rozwiniętych i słabo zurbanizowanych w krajach rozwiniętych. Badania potwierdziły, iż klastry funkcjonujące w gorszym otoczeniu instytucjonalnym są słabsze i węższe, co wskazywało na istotne znaczenie potencjału instytucjonalnego budowanego poprzez aktywną współpracę oraz wewnętrzne czynniki społeczno-kulturowe regionu.

Enright wskazuje na sześć koniecznych elementów strategii rozwoju struktur klastrowych (Enright 1998, s. 120):

- poprawę otoczenia biznesowego (m.in. poprzez uwzględnienie potrzeb i oczekiwań wspomaganych struktur klastrowych),

- dostarczanie informacji i danych o prognozach gospodarczych w celu identyfikacji szans i zagrożeń rozwojowych i w rezultacie umożliwienia prowadzenia działań „wyprzedzających”,

- stały rozwój infrastruktury i oferty edukacyjnej oraz szkoleniowej,

- wdrażanie skutecznych metod sieciowania firm,

- finansowanie otoczenia okołobiznesowego, w tym tworzenie struktur wsparcia wspomagających tworzenie nowych firm,

- tworzenie lepszej jakości relacji lokalnych, m.in. budowanie wzajemnego zaufania.

Do pozostałych czynników koniecznych do rozwoju struktur klastrowych wymienianych w literaturze przedmiotu należy zaliczyć:

- tworzenie struktur klastrowych w obszarach, które mają perspektywy rozwoju,

- koncentrowanie swojej aktywności na rynkach międzynarodowych, a nie regionalnych (tzn. koncentrowanie się „na zewnątrz”, a nie „do wewnątrz”).

Identyfikacja narzędzi wspierających rozwój struktur klastrowych jest równocześnie prezentacją najważniejszych barier funkcjonowania struktur klastrowych na terenach słabo zurbanizowanych, tj. typowych dla województwa podkarpackiego. Za Rosenfeldem zaliczyć do nich należy (Rosenfeld 2002, s. 45):

- niska jakość infrastruktury (w tym transportowej oraz informatycznej),

- brak dostępu do kapitału,

- niska jakość otoczenia innowacyjnego, w tym przede wszystkim niską jakość instytucji badawczo - rozwojowych oraz szkoleniowych,

- niedostateczne otwarcie firm „na zewnątrz” (ang. outward approach) - często firmy z regionu ,zamykają się w sobie” - szczególnie brak efektywnych mechanizmów identyfikowania i pozyskiwania wiedzy spoza regionu lub obszaru funkcjonowania firmy,

- niska jakość i niedostateczne kwalifikacje zasobów ludzkich,

- narzucana hierarchiczność funkcjonowania struktur klastrowych.

Rosenfeld proponuje narzędzia wspierania struktur klastrowych w siedmiu obszarach wsparcia, tj.:

Pierwszy obszar obejmuje monitorowanie struktury gospodarczej regionu w celu identyfikacji potencjalnych obszarów wsparcia. Proces monitorowania nie może ograniczać się wyłącznie do identyfikowania obszarów działalności gospodarczej o wysokim stopniu koncentracji, ale powinien obejmować również identyfikowanie i modelowanie relacji systemowych 
sektora z innymi obszarami działalności gospodarczej (np. analizy sektorowych łańcuchów dostawców, schematy przepływu wiedzy w ramach sektora oraz pomiędzy sektorami). Proces monitorowania powinien obejmować również elementy analizy porównawczej, w tym m.in. porównywania się do innych występujących lub powstających struktur klastrowych w następujących obszarach:

- oceny porównawczej bazy technologicznej i potencjału badawczo - rozwojowego,

- dostępności wykwalifikowanej siły roboczej,

- oceny poziomu i możliwości rozwoju zakumulowanej wiedzy w regionie,

- struktury, dostępności i poziomu technologicznego dostawców,

- dostępności kapitału,

- dostępności i jakości struktur szkoleniowych oraz systemu kształcenia,

- dostępności i jakości wyspecjalizowanych na potrzeby grona usług,

- zakresu i jakości powiązań kooperacyjnych w ramach klastra,

- stopnia przedsiębiorczości w regionie,

- poziomu działalności innowacyjnej i imitacyjnej w regionie i w ramach grona,

- obecności i jakości liderów innowacyjnych i przemysłowych operujących w ramach grona i w regionie,

- jakości relacji zewnętrznych i stopnia otwartości (w tym stopnia umiędzynarodowienia) regionu oraz klastra,

- wizji rozwoju klastra i regionu (kierunków, obszarów działalności).

Podstawowym obowiązkiem jest monitorowanie i analizowanie struktury gospodarczej regionu, przy zastosowaniu narzędzi analizy porównawczej, pod kątem możliwości rozwoju klastrów pomaga zrozumieć funkcjonowanie ekonomiczne regionów jako systemów gospodarczych i ekonomicznych oraz pozwala efektywniej identyfikować market imperfections.

Drugi obszar to tworzenie otoczenia instytucjonalno-organizacyjnego grona poprzez edukowanie, przekonywanie i angażowanie w proces wspierania i rozwoju struktur klastrowych instytucji okołobiznesowych, stowarzyszeń pracodawców, izb przemysłowo-handlowych, agencji rozwoju regionalnego, organizacji pracodawców. Jest to tzw. proces tworzenia kotwic rozwoju klastra poprzez kreowanie wspólnych działań (np. lobbowanie na rzecz regionu lub obszaru działalności na poziomie regionalnym bądź krajowym). W tym celu należy identyfikować wspólne potrzeby i cele instytucji wspierających przedsiębiorców i samych przedsiębiorców oraz stale prowadzić monitoring obecnych w regionie instytucji i organizacji w kontekście potrzeb grona. W razie konieczności należy pomóc tworzyć organizacje klastrowe poprzez współfinansowanie, pomagać formalizować kanały komunikacji, np. za pomocą stron internetowych, wspomagać i stymulować współpracę pomiędzy firmami.

Trzeci obszar to przygotowanie profesjonalnej oferty usług wspierających działalność struktur klastrowych zorientowanych na rozwiązywanie problemów identyfikowalnych i zgłaszanych przez firmy lub grupy firm. Do usług takich należą przede wszystkim:

- tworzenie systemu pozyskiwania i rozpowszechniania informacji,

- organizowanie kompleksowych punktów obsługi firm stowarzyszonych w klastrze oraz zaspokajających ich potrzeby i oczekiwania,

- przygotowanie administracji lokalnej i regionalnej do współpracy ze strukturami klastrowymi.

Czwarty obszar to poprawa jakości kształcenia i działalności szkoleniowej i wspomaganie procesu pozyskiwania wyspecjalizowanych kadr, kluczowych dla funkcjonowania i rozwoju klastra, oraz regionu, głównie poprzez:

- wspomaganie struktur klastrowych w zakresie wspólnego opracowywania programów szkoleniowych, 
- tworzenie klastrowych centrów umiejętności i doskonałości - współpraca z instytucjami naukowo-badawczymi,

- dofinansowanie specjalistycznych szkoleń.

Piąty obszar obejmuje stymulowanie i przyciaganie inwestycji w obszary działalności struktur klastrowych w regionie, a w szczególności:

- promowanie wielostronnych projektów inwestycyjnych,

- dofinansowywanie inwestycji o charakterze badawczo-rozwojowym,

- promowanie inwestycji z obszarów działalności wspomagania struktur klastrowych.

Szósty obszar to stymulowanie innowacyjności i przedsiębiorczości, a w szczególności:

- propagowanie konieczności podnoszenia innowacyjności firm,

- wspomaganie procesu tworzenia nowych firm, inkubatorów klastrowych,

- wspomaganie powstawania i rozwoju centrów technologicznych świadczących usługi na potrzeby grona,

- inwestowanie w infrastrukturę badawczo-naukową w obszarze funkcjonowania klastra.

Siódmy obszar to głównie podejmowanie działań promocyjnych i wyróżniających region,

a w szczególności:

- promowanie regionów poprzez promowanie marki grona,

- promowanie i wspieranie klastrów eksportowych,

- tworzenie możliwości identyfikacji regionów (seminaria, konferencje itp.).

Forma tworzenia grona wywiera istotny wpływ na funkcjonowanie i rozwój struktur klastrowych. Klastry powstające endogenicznie są wynikiem działania historycznie ukształtowanych czynników sprzyjających prowadzeniu działalności o określonym charakterze. Do tych czynników należą m.in.:

- korzystne położenie,

- dobre połączenia komunikacyjne,

- wysoki poziom infrastruktury technicznej,

- wysoka kultura pracy,

- tradycja,

- wysoki poziom wiedzy z danej dziedziny,

- baza naukowo-badawcza i inne.

Im więcej takich czynników ma dana lokalizacja, tym większe jest prawdopodobieństwo powstania, przetrwania i rozwoju klastra. Warte podkreślenia jest to, że wiele czynników endogenicznych rozwija się w długim czasie i możliwość ich świadomego i planowanego kształtowania jest w krótszych okresach bardzo ograniczona. W szczególności dotyczy to czynników miękkich, takich jak wiedza i umiejętności, normy i wartości, kultura pracy, aktywność społeczna. Wśród czynników endogenicznych olbrzymią rolę odgrywa tradycja. Jeśli w danym regionie zlokalizowane są podmioty określonej branży, to w sposób naturalny rozwija się tam infrastruktura techniczna i społeczna oraz naukowo-badawcza sprzyjająca danej działalności. Klastry powstałe w wyniku czynników endogenicznych są trwałe i stosunkowo odporne na kryzysy. Firmy należące do takiego klastra dysponują wieloma atutami wynikającymi z wymienionych przewag lokalizacji. Zagrożeniem dla nich może być kryzys całych branż, gdyż najczęściej przyjmują one postać zgrupowania większych i mniejszych firm działających w jednej branży (Zorska 2002, s. 69).

Do drugiej grupy należą klastry egzogeniczne - tworzone dzięki świadomym zabiegom określonych podmiotów. Są nimi najczęściej władze centralne lub lokalne, instytucje naukowo-badawcze, organizacje wspierania przedsiębiorczości i inne. Zgrupowania podmiotów powstające w wyniku procesów egzogenicznych mogą stać się klastrami pod pewnymi warunkami: 
- zgrupowanie musi być zwarte przestrzennie,

- musi istnieć więź między podmiotami - uczestnikami danego zgrupowania,

- tworzenie się klastra powinien koordynować dysponujący zasobami podmiot wiodący. Podmiotem takim może być osoba lub instytucja działająca w imieniu państwa lub samorządu, silna jednostka naukowo-badawcza, silne i duże przedsiębiorstwo będące kluczowym dostawcą lub odbiorcą dla innych firm.

Badania empiryczne struktur klastrowych napotykają na problem znacznego zróżnicowania metodologii badawczych, co prowadzi do trudności przy porównywaniu funkcjonowania i konkurencyjności różnych klastrów. W opublikowanych do tej pory badaniach zastosowano różne podejścia dostosowane zarówno do poziomu agregacji badania lokalnego, regionalnego, sektorowego czy narodowego, jak i do dostępnych danych statystycznych i jakościowych. Można wskazać na trzy podstawowe metody: metoda przepływów międzygałęziowych (input) output), metoda badania skupień (tzw. high points) oraz metoda oparta na analizie studiów przypadku. Tabela 2 przedstawia krótką charakterystykę poszczególnych metod.

\section{Obszary sieci współpracy w województwie podkarpackim}

Podkarpacie na tle innych województw jest średnim regionem w kraju zarówno pod względem powierzchni, jak też liczby mieszkańców (5,7\% powierzchni kraju i 5,5\% ludności). Region wypracowuje ok. 3,9\% produktu krajowego brutto i zajmuje 11 pozycję, jednak w przeliczeniu na 1 mieszkańca spada na przedostatnie miejsce ${ }^{4}$.

Niezwykle ważnym zasobem Podkarpacia, stanowiącym potencjał dla rozwoju przedsięwzięć o charakterze innowacyjnym w formie klastra, jest kapitał społeczny. Kapitał społeczny odnosi się do wewnętrznej, społecznej i kulturowej koherencji społeczeństwa, do norm i wartości, które kierują ludzkimi interakcjami, i do instytucji działających w regionie. Kapitał społeczny jest rodzajem spoiwa, które utrzymuje społeczeństwo jako całość i bez którego ekonomiczny wzrost bądź dobrobyt ludzki nie może zaistnieć (Jarmołowicz, Kościński 2005).

Kapitał społeczny Podkarpacia, dla którego charakterystyczny jest wysoki poziom wzajemnego zaufania i normy zaangażowania na rzecz dobra wspólnego, sprzyja wzrostowi gospodarczemu i jest czynnikiem integracyjnym w tworzeniu zaawansowanych form organizacyjnych działalności gospodarczej, jakimi są klastry.

W województwie podkarpackim, w oparciu o potencjalne warunki i czynniki rozwoju, wykształciły się trzy funkcje: przemysłowa, rolnicza, rekreacyjno-wypoczynkowa i turystyczna - w tych właśnie obszarach należy poszukiwać możliwości budowania sieci współpracy bazujących na endogenicznych czynnikach regionu. Głównym przemysłem jest branża niskotechnologiczna, tj. przetwórstwo spożywcze jako sfera potencjalnie najmniej innowacyjna. Dla Podkarpacia ważny jest silny przemysł spożywczy, który zapewni rynek zbytu lokalnym producentom rolnym. Dlatego też istotnym zadaniem jest rozwój grona rolno-spożywczego. Innowacyjność wymaga dużych nakładów na badania i rozwój, a następnie szybkiego wdrażania nowych technologii (produktu). W regionach relatywnie biednych, takich jak Podkarpacie, które jest mało atrakcyjne dla inwestorów zewnętrznych głównie ze względu na słabo rozwiniętą infrastrukturę komunikacyjną, szansy na przyśpieszony rozwój powinno się poszukiwać wewnątrz regionu. Należy wykorzystać te jego atuty, które przy właściwym ich wykorzystaniu mogą być silnym prorozwojowym czynnikiem. Na Podkarpaciu istnieje wiele podmiotów gospodarczych w branży spożywczej działających w obszarach nowoczesnych technologii, ale

\footnotetext{
${ }^{4}$ Dane GUS za 2008 r.
} 
Tab. 2. Metody wykorzystywane w procesie badania klastrów

\begin{tabular}{|c|c|c|c|}
\hline Metoda & Opis metody & Zalety & Wady \\
\hline input/output & $\begin{array}{l}\text { Opiera się na analizie powiązań } \\
\text { pomiędzy sektorami. W tradycyj- } \\
\text { nym podejściu wykorzystuje się } \\
\text { macierze przepływów produkcji. }\end{array}$ & $\begin{array}{l}\text { Pozwala w sposób } \\
\text { najbardziej pełny } \\
\text { i obiektywny ziden- } \\
\text { tyfikować istniejące } \\
\text { powiązania pomię- } \\
\text { dzy poszczególnymi } \\
\text { sektorami. }\end{array}$ & $\begin{array}{l}\text { Nie we wszystkich } \\
\text { krajach dostępne są } \\
\text { dane niezbędne do takiej } \\
\text { analizy. Pomija instytucje } \\
\text { wspierające. Niedoskona- } \\
\text { łość klasyfikacji sektoro- } \\
\text { wej przemysłów. }\end{array}$ \\
\hline $\begin{array}{l}\text { Metoda } \\
\text { macierzy }\end{array}$ & $\begin{array}{l}\text { W niektórych krajach OECD } \\
\text { wykorzystuje się również ma- } \\
\text { cierze innowacyjne bazujące na } \\
\text { macierzach interakcji zachodzą- } \\
\text { cych w procesie innowacyjnym, } \\
\text { które są konstruowane w oparciu } \\
\text { o dane uzyskane z przeprowa- } \\
\text { dzonych badań. Metoda ta zosta- } \\
\text { ła zastosowana w badaniu klastra } \\
\text { samochodowego w Niemczech. }\end{array}$ & $\begin{array}{l}\text { Dostarczają naj- } \\
\text { nowszych danych } \\
\text { o współzależno- } \\
\text { ściach zachodzących } \\
\text { w procesach inno- } \\
\text { wacyjnych oraz in- } \\
\text { terakcjach pomiędzy } \\
\text { różnymi grupami } \\
\text { przemysłów. }\end{array}$ & $\begin{array}{l}\text { Bardzo kosztowne. } \\
\text { Dane dostępne tylko } \\
\text { w nielicznych krajach } \\
\text { (np. w UE). }\end{array}$ \\
\hline $\begin{array}{l}\text { Współczynnik } \\
\text { lokalizacji }\end{array}$ & $\begin{array}{l}\text { Podstawą tej analizy jest obli- } \\
\text { czenie współczynnika lokali- } \\
\text { zacji (LQ - location quotient): } \\
\text { LQ = (Eij/Ej) (Ein/En), gdzie } \\
\text { Eij - zatrudnienie w przemyśle } \\
\text { (można również wykorzystać } \\
\text { inne kategorie ekonomiczne, np. } \\
\text { wartość dodana, dochody, liczbę } \\
\text { firm) i w regionie j, Ej - cał- } \\
\text { kowite zatrudnienie w regionie } \\
\text { j, Ein - krajowe zatrudnienie } \\
\text { w przemyśle i, En - całkowite } \\
\text { zatrudnienie w kraju. LQ = } 1 \\
\text { oznacza, że region posiada taki } \\
\text { sam udział zatrudnienia w danym } \\
\text { przemyśle, jaki ma gospodarka } \\
\text { narodowa. LQ większy niż } 1,25 \\
\text { jest zazwyczaj przyjmowany } \\
\text { jako świadczący o regionalnej } \\
\text { specjalizacji w danym sektorze. }\end{array}$ & $\begin{array}{l}\text { Pozwala na identy- } \\
\text { fikację koncentracji } \\
\text { danych przemysłów } \\
\text { i w związku } \\
\text { z tym może posłu- } \\
\text { żyć do wstępnej ana- } \\
\text { lizy potencjalnych } \\
\text { klastrów. }\end{array}$ & $\begin{array}{l}\text { Współczynnik lokalizacji } \\
\text { nie informuje o samych } \\
\text { klastrach oraz o powiąza- } \\
\text { niach pomiędzy sektora- } \\
\text { mi. Oparcie się wyłącznie } \\
\text { na tym wskaźniku jest } \\
\text { niewystarczające do } \\
\text { identyfikacji klastrów; } \\
\text { niezbędne jest posłużenie } \\
\text { się dodatkowymi uzupeł- } \\
\text { niającymi metodami, np. } \\
\text { metodą ekspercką. }\end{array}$ \\
\hline $\begin{array}{l}\text { Case study } \\
\text { (metoda } \\
\text { ekspercka) }\end{array}$ & $\begin{array}{l}\text { Opiera się na analizie danych } \\
\text { jakościowych. Informacje są } \\
\text { zbierane za pomocą wywiadów } \\
\text { z kluczowymi ,aktorami”, pane- } \\
\text { li, białego wywiadu itp. Często } \\
\text { wykorzystywana w badaniach } \\
\text { klastrów na poziomie mikro. }\end{array}$ & $\begin{array}{l}\text { Stosunkowo tania } \\
\text { i łatwa do przepro- } \\
\text { wadzenia. }\end{array}$ & $\begin{array}{l}\text { Subiektywne, nieuogól- } \\
\text { nione wyniki badań. Ba- } \\
\text { zuje tylko „na opiniach”. }\end{array}$ \\
\hline
\end{tabular}

Źródło: opracowano na podstawie Brodzicki T., Szultka S., 2002. 
większość z nich nie dysponuje takim kapitałem, aby pozwolił na samodzielne podejmowanie działań innowacyjnych. W regionie tym istnieje zaplecze badawczo-rozwojowe skoncentrowane głównie w kilku największych uczelniach realizujących wiele drobnych i rozproszonych tematów badawczych, lecz wyniki tych badań nie zawsze mogą być bezpośrednio wykorzystane w praktyce ze względu na brak środków. W takiej sytuacji najbardziej sensowną propozycją jest integracja tematyczna sił i środków istniejących przedsiębiorstw oraz instytucji dysponujących możliwościami badawczo-rozwojowymi w celu wykorzystania wspólnego potencjału znacznie powiększonego dzięki efektowi synergii.

Ważnym etapem badania klastrów jest analiza statystyczna zatrudnienia na poziomie lokalnym poszukująca specjalizacji poszczególnych terytoriów. Służy do tego współczynnik lokalizacji, za pomocą którego wyznacza się stopień koncentracji zatrudnienia w danej branży, w danym miejscu w porównaniu z resztą kraju. Współczynnik lokalizacji (LQ) oblicza się jako relację udziału danej branży w zatrudnieniu w danym regionie/powiecie do udziału danej branży $\mathrm{w}$ zatrudnieniu $\mathrm{w}$ kraju. LQ $=1$ oznacza, że region posiada taki sam udział zatrudnienia w danym przemyśle jak gospodarka narodowa. LQ większy niż 1,25 świadczy o regionalnej specjalizacji $\mathrm{w}$ danym sektorze, co oznacza potencjalne możliwości tworzenia klastrów (tab. 3).

Tab. 3. Wartość wyliczonego za 2008 r. wskaźnika LQ dla poszczególnych branż w województwie podkarpackim

\begin{tabular}{|l|c|}
\hline \multicolumn{1}{|c|}{ Branża } & Wskaźnik LQ \\
\hline Lotnicza & 10,6 \\
\hline Automatyka przemysłowa & 1,55 \\
\hline Informatyka & 1,90 \\
\hline Przemysł maszynowy & 1,35 \\
\hline Przemysł metalowy & 1,26 \\
\hline Przemysł spożywczy & 1,84 \\
\hline Przemysł meblarsko-drewniany & 1,35 \\
\hline Przemysł włókienniczo-skórzany & 1,30 \\
\hline
\end{tabular}

Źródło: obliczenia własne na podstawie danych GUS za 2008 r.

Badania koncentracji zatrudnienia w poszczególnych branżach województwa podkarpackiego ${ }^{5}$ oparte zostały na współczynniku lokalizacji LQ, określającym stopień koncentracji zatrudnienia w danej branży, w danym miejscu w porównaniu z resztą kraju, wykorzystywanym do oceny specjalizacji regionu. Wyniki badań dotyczących analizy koncentracji zatrudnienia w województwie podkarpackim przeprowadzone dla danych branż wg Polskiej Klasyfikacji Działalności dla podmiotów zatrudniających powyżej 9 pracowników za 2008 r. wskazywały, że w regionie Podkarpacia mogą występować przemysłowe grona przedsiębiorczości, w tym szczególnie grono spożywcze. Tezę powyższą potwierdzały obliczone dla poszczególnych

\footnotetext{
${ }^{5}$ Badania (dane dotyczące zatrudnienia na koniec 2007 r.) przeprowadzone zostały z wykorzystaniem metodyki opublikowanej przez Wojnicką E., Potencjalne grona na Podkarpaciu i formy ich wspólnych działań [w:] Analiza wspierania gron przedsiębiorczości na Podkarpaciu. Instytut Gospodarki WSIiZ w Rzeszowie, Rzeszów 2006.
} 
branż wskaźniki lokalizacji (LQ powyżej 1,25), które określały możliwości tworzenia następujących gron:

- wysoko technologiczne - lotnictwo i automatyka przemysłowa,

- średnio wysoko technologiczne - przemysł maszynowy, samochodowy i produkcja taboru kolejowego,

- średnio nisko technologiczne - przemysł metalowy, tworzyw sztucznych i mineralny,

- nisko technologiczne - spożywczy, drewniano-meblarski, odzieżowo-skórzany.

W regionie Podkarpacia spośród powyższych zidentyfikowanych skupisk największe możliwości funkcjonowania i rozwoju posiadają klastry:

- lotnictwo - jako branża wysoko technologiczna - ze względu na istnienie struktury klastrowej w postaci Doliny Lotniczej oraz fakt, iż jest to bardzo istotna specjalizacja regionu w skali krajowej. Ponadto wsparcie powstania i funkcjonowanie Doliny Lotniczej na Podkarpaciu jest jednym z priorytetów Narodowej Strategii Rozwoju Regionalnego na lata 2007-2013;

- informatyka - jako branża usługowa i wysoko technologiczna, ze względu na kluczową rolę informatyki jako katalizatora rozwoju regionu podkarpackiego oddalonego od głównych centrów rozwojowych kraju oraz o niskim poziomie urbanizacji. Ponadto, jak wskazują badania, informatyka jest najbardziej innowacyjną branżą w Polsce;

- przemysł spożywczy - jako przedstawiciel branż tradycyjnych i powiązanych z podstawową specjalizacją regionu - rolnictwem. Dla pomyślnego rozwoju grona spożywczego istotny jest rozwój rolnictwa, konkurencyjny rynek zbytu dla ich produkcji, a w szczególności przemysł spożywczy.

Ze względu na specyfikę regionu grono przetwórstwa spożywczego powiązane z rolnictwem jest kluczowym dla województwa o wysokim udziale rolnictwa, jakim jest Podkarpacie. Bieszczadzkie powiaty Podkarpacia to także potencjalne grona turystyczne.

Proces tworzenia grona spożywczego na Podkarpaciu zapewne nie będzie procesem szybkim i łatwym. Wyniki badań ankietowych ${ }^{6}$ potwierdziły, iż powstanie grona spożywczego w województwie podkarpackim warunkują czynniki zewnętrzne, tj. otoczenie prawno-administracyjne, rozwój infrastruktury, jakość instytucji okołobiznesowych, stopień wykorzystania technologii informatycznych i komunikacyjnych, struktura społeczna i demograficzna oraz poziom kompetencji i zasobów ludzkich. Identyfikacja czynników mogących stanowić bariery w tworzeniu i funkcjonowaniu klastra spożywczego oraz próba wskazania eliminacji tych barier to istotna działalność w procesie tworzenia grona spożywczego. Bariery ograniczające proces tworzenia grona spożywczego to głównie niska jakość infrastruktury, niedostateczne otwarcie firm na zewnątrz, brak dostępu do kapitału, niedostateczne kwalifikacje zasobów ludzkich. W procesie tym ważnym elementem pozostaje wyszczególnienie czynników wspierających klastry, ze szczególnym uwzględnieniem branży rolno-spożywczej, polegających głównie na analizie otoczenia gospodarczego, konkurencji, ocenie wspólnych działań na rzecz tworzenia otoczenia instytucjonalnego grona, stworzenia profesjonalnej oferty usług wspierających działalność struktur klastrowych, podniesienie jakości kształcenia i działalności szkoleniowej, korzystania ze źródeł wsparcia finansowego ze środków UE (ryc. 1).

${ }^{6}$ Wyniki badań ankietowych przeprowadzonych w 2007 r. wśród 90 przedsiębiorców przez Wydział Ekonomii Uniwersytetu Rzeszowskiego w ramach realizacji projektu badawczego „Tworzenie sieci współpracy w zakresie innowacji pomiędzy przedsiębiorcami z obszarów wiejskich a sektorem badawczo-rozwojowym na przykładzie wybranych powiatów w woj. podkarpackim" objętego dofinansowaniem ze środków EFS. 
Ryc. 1. Czynniki lokalizacji przedsiębiorstw grona spożywczego w województwie podkarpackim (\% wskazań)

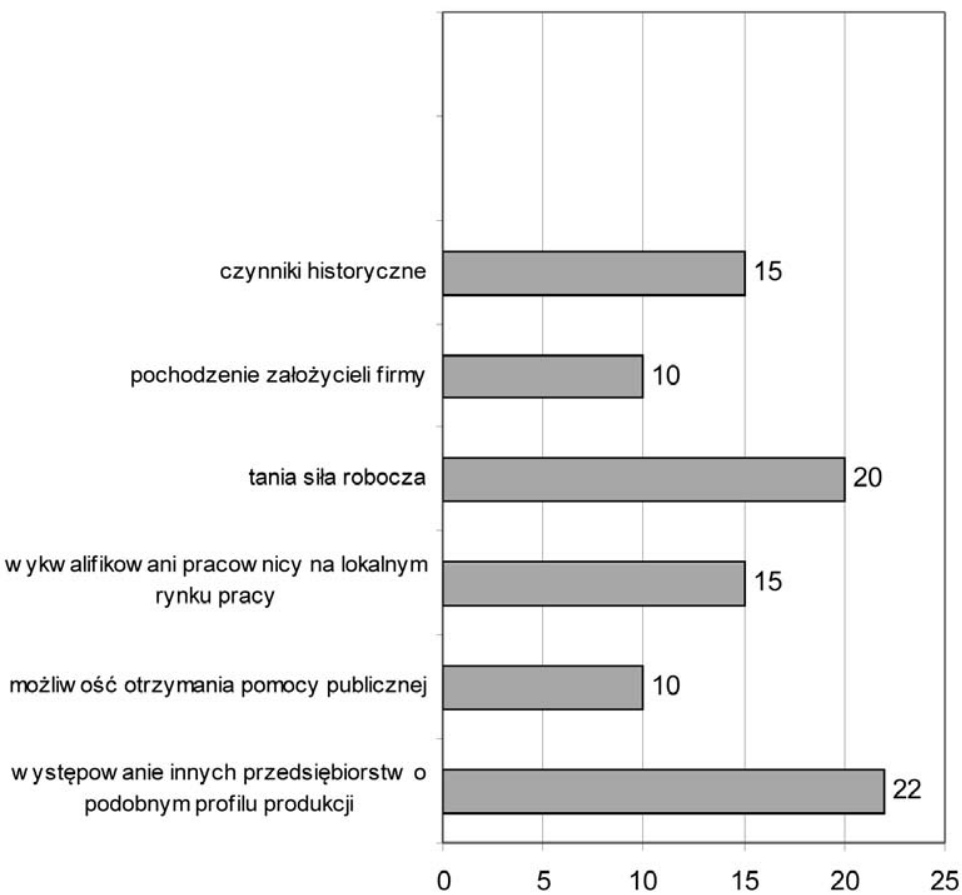

Źródło: opracowanie własne na podstawie badań ankietowych.

Etapem poprzedzającym proces tworzenia grona spożywczego powinna być szczegółowa charakterystyka sektora rolno-spożywczego na Podkarpaciu, stworzenie bazy danych dotyczącej firm w tej branży, ich działalności oraz instytucji otoczenia okołobiznesowego. Kolejne czynności to wyszczególnienie wszystkich argumentów przemawiających za tworzeniem grona spożywczego oraz wskazanie działań, jakie należałoby podjąć, aby uruchomić proces tworzenia gron z uwzględnieniem uwarunkowań regionu Podkarpackiego.

Jako czynnik motywujący proces tworzenia klastra spożywczego prezentowane będą doświadczenia w zakresie zacieśniania wzajemnych powiązań pomiędzy przedsiębiorcami innych podmiotów gospodarczych (głównie zagranicznych), które odniosły sukces w swojej branży i stanowią dobry przykład na tworzenie i sprawne funkcjonowanie struktur klastrowych.

Szczególnie istotne, ze względu na specyfikę regionu Podkarpacia, powinno być tworzenie sieci współpracy związanej z wykorzystaniem zasobów obszarów wiejskich. Takie szanse dają organizacje sieciowe $\mathrm{w}$ ramach gron tworzonych w agrobiznesie i w innych przedsięwzięciach związanych z zasobami lokalnymi obszarów wiejskich. Grona w obszarach wiejskich powinny powstawać w związku z tradycyjną produkcją żywności, a także z realizacją pozarolniczej funkcji tych obszarów. Istotne jest, aby w obszarach zagrożonych marginalizacją, do których należy Podkarpacie, wspierać rozwój takich sieci, które wykorzystują specyficzne zasoby lokalne. Zasięg geograficzny gron powinien być zbieżny z obszarem podregionów wydzielonych w regionie ze względu na podobieństwo wybranych cech. 


\section{Podsumowanie}

Podkarpacie jest jednym z najuboższych regionów Polski. Dlatego też konieczne są wszelkie działania mające na celu powiększanie siły przedsiębiorstw poprzez wykorzystanie korzyści skali i zakresu będące efektem funkcjonowania ich w formie klastrów. W województwie podkarpackim, mimo dominującego zatrudnienia w rolnictwie, istnieje potencjał rozwoju wielu klastrów w dziedzinach przemysłowych. Głównym przemysłem regionu jest branża niskotechnologiczna, tj. przetwórstwo spożywcze. Na Podkarpaciu dobrze rozwija się też informatyka jako branża usługowa oparta na wiedzy. Poza przeważającymi przedsiębiorstwami handlowymi czy naprawczymi powiązanymi z informatyką na Podkarpaciu występują też producenci oprogramowania. Ponadto występuje zaplecze naukowe stwarzające szansę na rozwój regionu w oparciu o informatykę. Jest to szczególnie istotne dla województwa o dominacji obszarów wiejskich, dla których komunikacja przez internet może stanowić „okno na świat”. Rozwój informatyki to instrument wspierający proces tworzenia klastra spożywczego na Podkarpaciu.

Dla wdrożenia Regionalnej Strategii Innowacji oraz przyśpieszenia rozwoju województwa wskazane jest wspieranie uznanych za światowe lokomotywy rozwoju branż wysoko technologicznych, ale także branż nisko technologicznych. Wyniki badań przeprowadzonych wśród przedsiębiorstw i instytucji powiązanych z tymi branżami wskazywały, że innowacyjność nie jest zarezerwowana wyłącznie dla branż wysoko technologicznych. Dla regionu Podkarpacia ważny jest silny przemysł spożywczy, który zapewni rynek zbytu lokalnym producentom rolnym. Dlatego też potencjalnym trzecim gronem jest sektor rolno-spożywczy.

Wyniki badań potwierdzają, że na Podkarpaciu można zidentyfikować rozpoczynający się proces tworzenia gron przedsiębiorstw, w tym także klastra spożywczego. W regionie tym poza Doliną Lotniczą będącą wykształconym klastrem w branży lotniczej nie występuje inny w pełni dojrzały klaster. Ze względu na brak idealnego modelu grona, konieczne jest wypracowanie przez lokalne środowisko własnej najlepszej drogi współpracy zwiększającej konkurencyjność. Ze względu na uwarunkowania społeczno-ekonomiczne województwa konieczne jest ciagłe monitorowanie struktury gospodarczej regionu w celu identyfikacji potencjalnych struktur klastrowych i ewentualnych obszarów wsparcia. Proces ciagłego promowania koncepcji klastrów wśród przedsiębiorców, jednostek otoczenia okołobiznesowego, administracji regionalnej jest ważnym czynnikiem budowania współpracy w formie gron.

\section{Literatura}

1. Adamowicz M., 2007, Sieci wspótpracy, grona i terytorialne systemy produkcyjne jako koncepcja rozwoju obszarów wiejskich, „Roczniki Naukowe SERiA”, t. IX, z. 2.

2. Grosse G., 2002, Przeglad koncepcji teoretycznych rozwoju regionalnego, „Studia Regionalne i Lokalne", nr 1(8), Warszawa.

3. Brodzicki T., Szultka S., 2002, Koncepcja klastrów a konkurencyjność przedsiębiorstw, „Organizacja i Kierowanie", nr 4, Warszawa.

4. Enright M., 1998, The Globalization of Competition and the Localization, Simon\&Schuster, New York.

5. Gurbała M., 2004, Rola przemystu zaawansowanej technologii w rozwoju regionalnym i lokalnym, WITE, Żyrardów.

6. Górzyński M., 2005, Tworzenie zwiazków kooperacyjnych między MŚP oraz MŚP i instytucjami otoczenia biznesu, ekspertyza wykonana na zlecenie Polskiej Agencji Rozwoju Przedsiębiorczości, Rzeszów. 
7. Górzyński M., 2006, System wspierania gron przedsiębiorczości-publikacja podsumowujaca. „Studia Europejskie” Instytut Gospodarki Wyższej Szkoły Informatyki i Zarządzania w Rzeszowie, nr 5, Rzeszów.

8. Jacobs J., 2000, The Nature of Ekonomics, New York.

9. Jarmołowicz W., Kościński M., 2005, Menedżerowie a kapitał społeczny organizacji [w:] Nierówności społeczne a wzrost gospodarczy, z. 7, Uniwersytet Rzeszowski, Rzeszów.

10. Knop L., Krannich M., Machnik-Słomka J., Wróbel P., 2005, Metodologia badań wstęnych w procesie tworzenia klastrów, TNOiK, Katowice.

11. Olechnicka A., 2004, Regiony peryferyjne w gospodarce informacyjnej, Wydawnictwo Naukowe SCHOLAR, Warszawa.

12. Porter M.E., 2001, Porter o konkurencji, PWE Warszawa.

13. Porter M.E., 1995, Strategia konkurencyjności, PWE, Warszawa.

14. Ketels Ch., 2003, The Development of the cluster concept, Harvard Business School.

15. Moss R., 1995, Kantor World Class, Simon\&Schuster, New York.

16. NSR na lata 2007 - 2013, www.nsr.gov.pl

17. Rosenfeld S.A., 2002, Creating Smart Systems. A. Guide to Cluster Strategies in Less Favoured Regions, Regional Technology Strategies.

18. Rothwell R., Successful industrial innovation: critical faktors for the 1990s. R\&D Management 2(3) 1992.

19. Wojnicka E., 2006, Analizy wspierania gron przedsiębiorczości na Podkarpaciu, Studia Europejskie 1/2006 Instytut Gospodarki WSiZ w Rzeszowie.

20. Zorska A., 2002, Ku globalizacji? Przemiany w korporacjach transnarodowych $i$ w gospodarce światowej, PWN, Warszawa.

\section{Determinants of Creating a Cooperation Network in the Region of Podkarpacie}

Cooperation networks (clusters, circles, groups, concentrations) of enterprises are inherent elements of the present economic model. By creating an innovative regional policy, which is aimed at the long term goal of the creation of clusters, the process of increasing innovation in the region and the stimulation of particular enterprises is encouraged. The local system of information is the cluster which should provide data on scientific achievements, the possibilities of introducing innovations as well as help to secure capital, information on promotion and marketing. The process of creating cooperation networks is significant not only for entrepreneurs but also for the authorities and self-government activists responsible for stimulating the processes of local and regional development. Within the period of European Union membership, development support programmes have emerged, which are based on structural funds and assigned for not only clusters but also broader cooperative connections.

By focusing on the region of Podkarpacie and gauging its competitiveness, an attempt has been made to identify the determinants influencing this process of change. It mainly concerned the creation of cooperation networks and other forms of co-action, whose implementation and organisation in the region of Podkarpacie require active steps to be taken by those institutions responsible for regional development. The analysis performed on the basis of statistical data published by the Main Statistical Office covers 2004-2008. The assessment of this material attempts to interpret the necessary conditions for growth of the cooperative network in the region of Podkarpacie. 